\title{
Exchange rate volatility and Economic growth in Ghana
}

\author{
Eunice Adjei \\ Academic City College \\ Accra- Ghana.
}

\begin{abstract}
This study has primarily sought to estimate the exchange rate volatility and to examine the effect of exchange rate volatility on economic growth in Ghana. The investigation covers the period between 1983 and 2010.The variables of concern were five in all which included Exchange rate volatility and Trade Openness, GDP per capita and Physical capital stock and Human capital stock. The ARCH and GARCH Models introduced by Engle (1982) and Bollerslev (1986) were used to model the volatility of the exchange rate using monthly data from January 1983 to December 2010. The exchange rate volatility variables generated were then used in the growth determinant function. The time series analysis the study employed is the Autoregressive Distributed Lag Approach (Peaseran et al, 2001) to analyse the relationship between exchange rate volatility and economic growth in Ghana. From our estimation results, the conclusion drawn was that exchange rate volatility exerted significant negative effect on economic growth during the period both in the short and long run. This is because of the high risk in investing hence discouraging international trade and growth. As recommendations for policy implementation, policy makers' should aim at stabilizing the exchange rate as that will encourage investors and improve productivity and trade hence good economic performance. Again policy makers need to strength the local industry so as to boost production. When the local production industry is strengthened, it will also reduce the quantity of imports. There should be subsidies and grants to the local industry as well as to boost exports as that will increase trade and boost economic performance.
\end{abstract}

Keywords: Exchange rate, volatility, Economic growth, Ghana.

\subsection{Introduction}

Exchange rate volatility has been defined as the persistent fluctuation of the exchange rate (Alagidede\& Ibrahim, 2017). Exchange rate management is important in economic development globally and more particularly in Ghana, because it has contributed not only to economic instability but also political instability. According to Bhasin (2004), exchange rate stability is necessary for the stability of prices in Ghana because the economy is heavily dependent on imports of raw materials, capital goods, and consumer goods. Essentially, a stable exchange rate would have positive effects on household incomes and consumption decisions, governments' fiscal, monetary policies, and trade balance.

The real exchange rate, by virtue of its impact on the international competitiveness of an economy, assumes an overriding importance among policy variables in Ghana (Alagidede\& Ibrahim, 2017). The recent instability in the real exchange rate has raised questions as to whether this trend will impact either positively or negatively in the Ghanaian economy. In Ghana, the management of the exchange rate is carried out by the Bank of Ghana which is the central bank. Even though there was a brief attempt at liberalizing the trade and exchange rate regime between 1967 and 1971, this was terminated and Ghana returned to a fixed exchange rate regime.

Following the adoption of the Economic Reform Programme (ERP) in 1983, it changed the nature of exchange rate policy and the country eventually liberalized into a flexible rate system. The real exchange rate however depreciated considerably during this period. Despite various efforts by the Government of Ghana (GoG) to maintain a stable exchange rate, the cedi has been depreciating considerably (Amoah et al. 2017; Mensah et al. 2017).

Previous research on the impact of exchange volatility on growth found diverse views on this issue. Aliyu (2009) found that appreciation of exchange rate exerts positive impact on real economic growth in Nigeria. Razazadehkarsalari et al (2011) identified that in Iran, during stagnation and low price period, depreciation of currency has positive and significant effects on real GDP whiles in high price period depreciation of the exchange rate has insignificant effects on real GDP. David et al (2010) examined the effect of exchange rate fluctuations on Nigerian manufacturing industry. They employed multiple regression econometric tools which revealed a negative relationship between exchange rate volatility and manufacturing sector performance. Jin (2008) carried out a comparative study and found that appreciation of exchange rate increases GDP in Russia while it reduces GDP in Japan and China. 
Abeysinghe\& Yeok (1998) suggested that exchange rate deprecation stimulates exports and restrain imports, while exchange rate appreciation reduce exports and encourage imports. Aizenman (1992) and Goldberg (1993) found that increase in exchange rate volatility is associated with reductions in the level of investment. Coleman \&Agyire- Tetteh (2008) argue that fluctuations, whether positive or negative, are undesirable as they have the tendency of increasing risk and uncertainty in international transactions, thereby discouraging trade and investment flow. The review of literature shows the absence of studies linking exchange rate volatility to economic growth in Ghana. The closest study by Alagidede\& Ibrahim (2017) looked at the causes and effect of exchange rate volatility in Ghana. This means that research gap exists in terms of the effect of exchange rate volatility and its influence on economic growth in Ghana

Furthermore, from the above discussion, it can be inferred that the relationship between exchange rate volatility and economic growth is far from being conclusive in the literature. Furthermore, exchange rate volatility can be reduced by hedging against risk and uncertainty in international transactions, through the use of futures or forward contracts. Unfortunately, such a futures or forward market is virtually non-existent in the Sub-Saharan region in general and Ghana in particular, thereby reducing the possibility of hedging against the volatile nature of the exchange rate.

The thrust of this study is to examine the effect of real exchange rate volatility on economic growth, with evidence from Ghana. This has become necessary as Ghana seeks to grow the economy by attracting more investors in the light of rising fluctuation of the Ghanaian cedi against major currencies around the world. The fluctuation and instability in the cedi has been more profound with the inception of the liberalization of the exchange rate. This paper also attempts to fill a gap, as no study has attempted to analyze the relationship between the volatility of the Ghanaian cedi and its effect on the growth of the economy. The study makes significant contributions to literature and policy debate in Ghana. Studying the relationships between economic growth and the real exchange rate is especially important for Ghana, since the real exchange rate can be used as a strategy or policy tool in Ghana's bid to reduce poverty within the context of export-led growth.

As a key relative price in the economy, the real exchange rate may not only alter the country's external balance but also other more socially sensitive variables such as income distribution, poverty, and employment. A better understanding of whether exchange rate volatility boosts or hinders economic growth would certainly have useful implications for the exchange rate, fiscal, and monetary policies. The study is among few studies in developing countries and Africa that have examined the impact of exchange rate volatility on economic growth. The study therefore adds to the scanty literature on the subject matter especially in Africa and Ghana.

\subsection{Literature Review}

\subsection{Ghana's Exchange Rate Policy: ERP Era (1983-1990)}

The economic trajectory outlined above suggests the necessity of a major change in policy if the sharp decline of the economy in 1970s and early 1980s was to be arrested. In the words of National Programme for Economic Development (July, 1987), a policy change was necessary for the "arrest and reversal of over a decade of precipitous decline in the production in all sectors of the community (and) rationalization of the exchange rate in order to stimulate exports and make the scarcity of foreign exchange a factor in official pricing'.

In response to these difficulties, the military government, Provisional National Defence Council (PNDC), headed by Jerry John Rawlings accepted stringent International Monetary Fund and World Bank loan conditions, which included fiscal stringency, devaluation of the currency and liberalization of the financial market under the Economic Recovery programme (ERP). The programme was launched in April 1983 with the main objectives of removing price and trade controls and liberalizing the exchange rate. The four basic objectives of the reforms of the foreign exchange regime include:

1. Realigning the official exchange rate;

2. Absorbing the parallel market into the official market;

3. Achieving a convergence of official and parallel exchange rates;

4. Allowing the forces of demand and supply to determine foreign exchange rate and to allocate foreign exchange (Dordunoo, 1994).

With the launching of the economic reform programme, six different phases of the exchange rate reform were implemented, which include:

- Multiple exchange rate system

- Dual-Window system;

- Unified auction system;

- Foreign exchange bureaus system; 
- Wholesale Dutch auction system;

- Inter-bank market system.

\subsection{Ghana's Exchange Rate Policy: Floating Exchange Rate Regime (1990 - to 2010)}

The exchange rate regime actually started in 1990 with the introduction of inter-bank market transactions and wholesale auction system. However, it is only the inter-bank market that has operated in the foreign exchange transactions since 1992 and continued to present, when wholesale auction system was abolished in April, 1992. This regime was characterized by a flexible exchange rate regime in the form of managed floating in which the exchange rate was determined by demand and supply factors. Under this regime, the management of the exchange rate took place directly in the inter-bank market, with Bank of Ghana's intervention in the foreign exchange market aiming only to smooth short-term exchange rate fluctuations through the supply of foreign exchange to the banks, without any preannounced path or target for the exchange rate. Since major foreign exchange transactions took place at the inter-bank level, the official exchange rate is first determined by the official exchange rate to cater for the needs of travellers and traders who trade with the neighboring countries. The flexible exchange rate policy adopted in 1992 resulted in large exchange rate depreciation until 2001, when prudent fiscal and monetary policies were embarked upon to arrest the high depreciation and volatile nominal and real exchange rate. The real exchange rate depreciation, however, helped improve Ghana's external competitiveness and strengthened the incentives for export growth (Asenso-Okyere\& Yahaya, 1993).

\subsection{Empirical Literature on Exchange Rate Volatility and Economic Growth}

It is a general believe that appreciation of currency expands imports and reduce export while depreciation increase cost of importation thereby discouraging import and encouraging export. However, theoretical and empirical evidence on the effect of exchange rate volatility on economic performance has produced mixed pattern of results providing positive and negative effects.

Empirical studies are concentrated most of the time on the selection of exchange rate systems i.e. fixed or flexible. Studies demonstrate a discrepancy in terms of their findings regarding the impacts of exchange rate volatility on indicators of real economy. Differences in studies take place because of differences in types of exchange rates, the time of analysis, the place of analysis, and the methodology used for analysis.

The main intuition behind the difference in findings is that the increase in exchange rate volatility leads to uncertainty, which might have different impacts for different countries on both domestic and foreign investment decisions, trade, and other sources of economic growth. The studies have explored various channels through which exchange rate volatility linked (positively/negatively) with real economy.

Kormendi \& Meguire (1985) and Grier \& Tullock (1989) are among the first who explore the relationship between volatility and growth empirically. Both reported positive impact of standard deviation of GDP growth on its mean. Nevertheless, Ahmed (2009), being one of the last in literature so far investigated impact of exchange rate volatility on growth using quarterly data for Bangladesh trade with North America, Western Europe, Eastern Europe, SAARC, ASEAN, and Asia- Pacific regions. The study points out that the volatility of exchange rate has a negative and significant effect in the long run as well as in the short run. On the other hand, Ghosh et al. (2003) find weak evidence that exchange rate affects growth in a positive or negative way.

In literature, Hooper \& Kohlhagen (1978) are among the first ones who analyzed systematically the effects of exchange rate volatility on trade. In this study, exchange rate risk is measured by standard error of nominal exchange rate fluctuations. Any significant link could not be established by them, and inconsistent results regarding the impact of exchange rate volatility on international trade are being observed.

Frankel \& Rose (2002) using data for more than 200 countries suggest that belonging to a currency union triples trade with other currency union members. They also report that every one percent increase in a country's overall trade relative to GDP raises income per capita by at least one third of the percent. The hypothesis that the volatility of exchange rate decreases the volume of international trade is supported by Akhtar \& Hilton (1984), Kenen \& Rodrick (1986), Thursby \& Thursby (1987), De Grauwe (1988), Koray\& Lastrapes (1989) and Arize (1995). Hooper \& Kohlhagen (1978), Gotur (1985), Asseery and Peel (1991) and Bacchetta \& Wincoop (2000) reported no impact of the exchange rate volatility on trade.

Empirical evidence carried out on the negative effect of exchange rate volatility on trade (and thereby Growth) in small open developing economies has remained mixed (European Commission, 1990; IMF 1984). Arize (1998) concluded that there is a negative effect of exchange rate volatility on imports as well as exports and this effect is significant in the long and short run. 
The idea of risk transfer from highly volatile investment to less risky ones by risk adverse investors led many researchers to suggest that there exists a negative effect of exchange rate volatility on volume of trade because of increase in this risk level (De Grauwe, 1988).

Akhtar and Hilton (1984), Kenen\& Rodrik (1986), Obstfeld\& Rogoff (1998), Persson\& Svensson (1989), have created adverse influence of exchange rate uncertainty on imports and exports. Obstfeld\& Rogoff (1998) stated that exchange rate flexibility generates significant problems for both exporters and importers. Risk adverse investors invest in export so as to have less worry about the changes in exchange rate and prevent sudden loss of revenue (Mahmood and Ali, 2011).

Barkoulas et al (2002) examined the impact of exchange rate fluctuation on the volume and variability of trade flows. They concluded that, exchange rate volatility discourages expansion of the volume of trade thereby reducing its benefits. Eichengreen \& Leblang (2003) carried out their research in 12 countries over a period of 120 years and found strong inverse relationship between exchange rate stability and growth. They concluded that the results of such estimations strongly depend on the time period and the sample.

Schnabl (2008) also identified robust evidence through panel estimation that exchange rate stability is associated with more growth in the European Monetary Unit (EMU) periphery. The evidence, according to him, is strong for Emerging Europe which has moved to more stable environment. Giovanni (2005) suggested empirically the impact of trade cost on real exchange rate volatility. Glauco \& Abott (2004) investigated that exchange rate uncertainty has a significant influence on UK exports to EU countries.

Furthermore, David et al. (2010) examined the effect of exchange rate fluctuations on Nigerian manufacturing industry. They employed multiple regression econometric tools which revealed a negative relationship between exchange rate volatility and manufacturing sector performance. Jin (2008) carried out a comparative study and found that appreciation of exchange rate increases GDP in Russia whiles it reduces GDP in Japan and China.

Razazadehkarsalari, et al. (2011) identified in Iran that during stagnation and low price period, depreciation of currency have positive and significant effects on real GDP while depreciation has insignificant effects on real GDP in high price period. Aliyu (2011) found that appreciation of exchange rate exert positive impact on real economic growth in Nigeria.

Doganlar (2002) analyzed empirically the impact of exchange rate instability on the export of five Asian countries including Pakistan, Turkey, South Korea, Malaysia and Indonesia. The results indicate that there is a long run relationship exists between real exports, foreign activity, relative prices and exchange rate volatility. Zhang (2000) says that inflation occurs in the end due to devaluation of the currency. Esquivel et al. (2002) described exchange rate volatility has certainly played a role in reducing exports in developing countries.

Virgil (2001) investigated that the long run relationship between Turkey's real exports and its exchange rate instability is negative but statistically significant for Germany, France and the United states. Abeysinghe\& Yeok (1998) suggested that exchange rate deprecation stimulates exports and restrain imports, while exchange rate appreciation would reduce exports and encourage imports.

Brada \& Mendez (1988) tested whether flexible exchange rates reduce the volume of international trade more than do fixed rates. They assumed that differences between the volumes of trade with two types of partners should reflect systematic differences on commercial policy between fixed and floating regime countries. Brada\& Mendez (1988) used gravity model of bilateral trade flows, which premise that bilateral trade between two countries is positively related to their respective incomes and negatively to the distance between them. They used bilateral trade flows among thirty developed and developing countries from 1973 to 1977, a period that includes both turbulent and tranquil times of exchange rates volatility. The result showed that bilateral trade flows among countries with the floating exchange rates are higher than those among countries with fixed rates. Inevitably, exchange rate uncertainty does lower the volume of trade among countries regardless of the nature of their exchange rate regimes, its effects are less than the trade reducing effects of respective commercial policies imposed by fixed exchange rate countries.

Bahmani-Oskooee \& Kovyryalova (2008) investigated the impact of exchange rate uncertainty on trade flows. Rather than using aggregate import and export data between one country and the rest of the world or between one country and her major trading partners they concentrate on 177 commodities traded between the United States (US) and the United Kingdom (UK) and employed cointegration and error-correction techniques to analyze the data covering 1971-2003. The results revealed that the volatility of the real bilateral dollar-pound rate has a short-run significant effect on imports of 109 and exports of 99 industries. In most cases, such effects are adverse. 
They also found that the number of significant cases is somewhat reduced in the long run with imports of 62 and exports of 86 industries which are significantly affected by the exchange rate volatility. They concluded that in most cases the effect is negative supporting the opponents of floating rates.

Similar study by Bahmani-Oskooee \& Wang (2008) determine whether a country's comparative advantage commodities are adversely affected by exchange rate volatility, they decomposed bilateral exports and imports between two countries into industry level data and concentrate on one of the major trading partners of Australia i.e. the US, and employ data from 107 industries that engage in trade between the two countries. They equally employ methodology that distinguishes the short run effects from the long-run effects i.e. bounds testing approach to cointegration and errorcorrection modeling. The empirical results show that exchange rate uncertainty has short-run effects on imports and exports of majority of the industries for which data was available (60\% of the cases).

However, the short run effects last into the long run only in the limited number of industries, though number of US importing industries affected in the long run were found to be almost twice as many as US exports by industries. Alternatively, exchange rate uncertainty affects Australian exports to the US more than it affects her imports.

In contrast to the studies that reveal negative relation between exchange rate volatility and trade flows, Koray\& Lastrapes (1989) produced contrary result, their study focus on the relationship between the real exchange rate volatility and bilateral imports of the united states(US) from the United Kingdom(UK), Germany, France, Japan and Canada.They constructed a vector autoregressive (VAR) model and estimated for each bilateral case using monthly data from 1959 to 1989 .Overall the evidence from the general time series model for the countries suggests a weak relationship between US bilateral trade flows and a measure of exchange rate variability.

Furthermore, two results emerge from the empirical investigation by Lee (1999). First neither price nor volume is significantly affected by the volatility of the exchange rate. The effect on prices is hardly significant. The conventional negative effect of the volatility on volumes vanishes when relative prices are included in the regression.

Secondly, the volatility of the exchange rate depresses import prices of durables more strongly than those of nondurable. The difference is statistically significant for relative prices but not for volume. This is consistent with the basic hypothesis that the volatility has a negative effect on demand for durable imports. However, Herwartz \& Weber (2005) found weak causal links operating from exchange rate uncertainty to trade growth for the 15 industrialized countries.

The empirical literature concerning the effect of ERV on trade flows in Nigeria also delivers mixed results, Ibikunle \& Isaac (2011) found inverse and statistically insignificant relationship between aggregate trade and ERV. Aliyu (2010) finds stable and long run equilibrium relationship between non-oil exports and the Naira exchange rate. Similarly, in a panel study that comprises some ECOWAS countries including Nigeria, Omisakin et al (2010) found significant relationship between trade flows and ERV for the selected countries.

Another way to analyze the impact of real exchange rate volatility on the real economy is to check its impact on investment. The literature provides evidence that uncertainty decreases investment in the presence of adjustment costs. If the investment projects are irreversible then uncertain environment leads to delay in investment decisions by investors to obtain more information about the real exchange rates. This exerts negatively on economic performance. Campa\& Goldberg (1993) report a negative impact of exchange rate volatility on investment.

Similarly, Barlevy (2004) using AK models with concave investment function show that volatility of the exchange rate lowers growth through the volatility of investment. On the other hand, using AK models Mendoza (1994) and Jonesand Wilson (1989) show that high risk will increase growth for individuals having high degree of relative risk aversion. Aizenman (1992) also reported a positive relationship, whereas Campa \& Goldberg (1995) find almost no impact between these variables. Aizenman (1992) and Goldberg (1993) found that increase in exchange rate volatility is associated with reductions in the level of investment.

Cushman (1985) analyzed the connection between real exchange rate uncertainty (volatility) and FDI, assuming various relationships between foreign and domestic production. He concluded that in response to exchange rate risk, multinational firms reduce exports to the foreign country but offsets this by increasing foreign capital input and production. Empirical studies on the connection between FDI and uncertainty in the case of developing countries are very few.

\subsection{Methodology}

\subsection{Data Source and Description}

This study uses a time series data spanning from 1983-2010 being the period from the introduction of the Economic Reform Programme (ERP) which changed the nature of exchange rate policy in Ghana and eventually liberalized into a flexible exchange rate system. 
Thus for the study period of January 1983 to December 2010, monthly data were used in estimating exchange rate volatility whiles a total of twenty eight (28) annual data values were used in estimating the entire model. All the data are secondary data and the main source of the data for all variables employed was taken from World Bank African Development Indicators and the International Financial Statistics. Most definition for the variables was adapted from the World Bank African Development Indicators. This information will be used to establish the study purpose and research objectives, to describe relevant study concepts and themes. For all variables, yearly data is employed for the simple reason that, most of the data are only available on a yearly basis. All the variables used in this study are of quantitative nature.

\subsection{Measuring the effect on Exchange rate volatility on Economic Growth}

\subsubsection{Model Specification}

The model specification follows the general approach to endogenous growth models that rely on firm production function of the form;

$Y_{t}=A_{t} F\left(K_{t} L_{t} H_{t}\right)$

Where ' $H$ ' represents the aggregate stock of knowledge; ' $K$ ' stands for capital; and ' $L$ ' for Labour, A represents the level of technology and the subscripts $t$ represent time period.

Following Romer (1986), equation (4) suggests that investment in knowledge leads to a natural externality, thus the production of knowledge by one firm is assumed to have positive external effects on other firms. Now relating the production function in equation (4) to aggregate production function that relates Gross Domestic Product (GDP) at time $t$ to factors of production leads to equation (5).

$Y_{t}=A_{t} K_{t}^{\omega} L_{t}^{\tau} H_{t}^{\rho}$

Adopting also from Graff et al (2003), I rearrange the production function and divide equation (5) by L, this gives us;

$$
\begin{gathered}
\frac{Y_{t}}{L}=\frac{A_{t} K_{t}^{\omega} L_{t}^{\tau} H_{t}^{\rho}}{L} \\
\gg \frac{Y_{t}}{L}=A_{t} *\left(\frac{K_{t}^{\omega}}{L^{\omega}} * L^{\omega}\right) \frac{L_{t}^{\tau}}{L} *\left(\frac{H_{t}^{\rho}}{L^{\rho}} * L^{\rho}\right) \\
\gg \frac{\boldsymbol{Y}_{\boldsymbol{t}}}{\boldsymbol{L}}=\boldsymbol{A}_{\boldsymbol{t}} *\left(\boldsymbol{K}_{\boldsymbol{t}} / \boldsymbol{L}\right)^{\boldsymbol{\omega}} *\left(\boldsymbol{H}_{\boldsymbol{t}} / \boldsymbol{L}^{\boldsymbol{\rho}} * \boldsymbol{L}^{\boldsymbol{\omega}+\boldsymbol{\tau}+\boldsymbol{\rho}-\mathbf{1}} \ldots \ldots \ldots\right.
\end{gathered}
$$

Taking the log of eqn (4) leads to

$$
\log \left(Y_{t} / L\right)=\log \left(A_{t}\right)+\omega \log \left(K_{t} / L\right)+\rho \log \left(H_{t} / L\right)+(\omega+\tau+\rho-1) \log L
$$

Differentiating eqn (5) with respect to time gives us eqn (6) in terms of growth rate;

$g(Y / L)_{t}=g\left(A_{t}\right)+\omega g(K / L)_{t}+\rho g(H / L)_{t}+(\omega+\tau+\rho-1) g(L)_{t}$

Where

$\boldsymbol{g}(\boldsymbol{Y} / \boldsymbol{L}){ }_{t}$ representthecontinuous growthrateinGDPpercapita, $g\left(A_{t}\right)$ representthecontinuous growthrateintechnology, $g($ capital formation (GCF) and

$g(H / L)_{t}$ is the continuous growth rate in human capital stock (level of knowledge) per worker proxied by secondary school enrolment rates (SCER)

Following Graff et al (2003), assuming constant returns to scale in $k, l$ and $h$, thus $(\boldsymbol{\omega}+\boldsymbol{\tau}+\boldsymbol{\rho})=\mathbf{1}$, which implies that $\mathrm{g}(\mathrm{L})$ drops out from the right hand side of eqn (8) and the growth rate of the overall level of technology or efficiency $g$ $\left(A_{t}\right)$ itself can be modelled as a function of a set of further variables.

$$
g(A)_{t}=\alpha_{0}+\alpha_{1} \operatorname{In}(Y / L)_{t-1}+\alpha_{2} X_{t} \ldots \ldots \ldots \ldots \ldots . .(9)
$$

Where $\operatorname{In}(Y / L)_{t-1}$ represents the lag of output or real GDP per capita, and $\mathrm{X}$ is a variable matrix containing a large number other possible determinants of economic growth. These include the variable of exchange rate volatility $(E R V)$ and the level of openness to international trade $(T O P)$ measured as the ratio of the sum of export and import to GDP (Azeez et al.,2012).

Substituting the other determinants of economic growth into equation (9) yields

$$
g(A)_{t}=\alpha_{0}+\alpha_{1} \operatorname{In}(Y / L)_{t-1}+\alpha_{2} E R V_{t}+\alpha_{3} T O P_{t}
$$

Replacing elaborate form of equation (9.1) into equation (8) for Ghana's growth regressions yields equation (10) below; 


$$
\begin{aligned}
& g(Y / L)_{t}=\alpha_{0}+\alpha_{1} \operatorname{In}(Y / L)_{t-1}+\alpha_{2} E R V_{t}+\alpha_{3} T O P_{t}+\omega \mathrm{g}(K / L)_{t}
\end{aligned}
$$

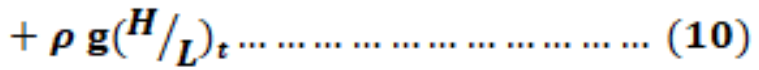

Therefore Ghana's growth regression yields equation (10.1) below

$$
\begin{aligned}
& g(G D P P C)_{t}=\beta_{0}+\beta_{1} \operatorname{In}(g G D P P C)_{t-1}+\beta_{2}(E R V)_{t}+\beta_{3}(T O P)_{t}+\beta_{4} g(G C F)_{t} \\
& +\beta_{5} g(S C E R)+\varepsilon_{t} \\
& \text { Variable Description }
\end{aligned}
$$

Growth rate of GDP per capita (annual \%)g(GDPPC) -

Annual percentage growth rate of GDP per capita based on constant local currency. GDP per capita is gross domestic product divided by midyear population. GDP at purchaser's prices is the sum of gross value added by all resident producers in the economy plus any product taxes and minus any subsidies not included in the value of the products. It is calculated without making deductions for depreciation of fabricated assets or for depletion and degradation of natural resources. The derivative of the log of real GDP per capita with respect to time is used in estimating economic growth. Source; World Bank national accounts data, and OECD National Accounts data files

\section{Trade Openness - TOP}

Trade openness is a policy variable that measures the level of international transactions undertaken by a nation. This variable is a measure of the total sum of trading with the out world. It is measured as the ratio of the sum of exports and imports to the value of GDP [(Exports + imports) /GDP]. Source; World Trade Organization and World Bank GDP estimates.

\section{Growth rate of the level of Physical Capital stock proxied by Gross Capital formation (GCF)}

The gross capital formation is used as a proxy for the level of physical capital in the Ghana. Gross capital formation (formerly gross domestic investment) consists of outlays on additions to the fixed assets of the economy plus net changes in the level of inventories. Fixed assets include land improvements (fences, ditches, drains, and so on); plant, machinery, and equipment purchases; and the construction of roads, railways, and the like, including schools, offices, hospitals, private residential dwellings, and commercial and industrial buildings.

\section{The Level of Human Capital (SCER)}

The average years of schooling (Secondary) rates is used as proxy for the stock of human capital. This variable is retrieved from world Bank Development Indicator .Gross enrollment ratio is the ratio of total enrollment, regardless of age, to the population of the age group that officially corresponds to the level of education shown. Secondary education completes the provision of basic education that began at the primary level, and aims at laying the foundations for lifelong learning and human development, by offering more subject- or skill-oriented instruction using more specialized teachers. Source; United Nations Educational, Scientific, and Cultural Organization (UNESCO) Institute for Statistics.

\section{Exchange Rate Volatility (ERV) :}

The exchange rate volatility variable is derived from monthly real exchange rate from January 1983 to December 2010. The Generalised Auto Regressive Conditional Heteroscedasticity (GARCH) process was used in estimating the exchange rate volatility variable. Source: International Financial Statistics.

\subsection{Analysis and Discussion}

\subsection{Descriptive Statistics of Regression Variables}

The mean, maximum and minimum values of the raw data are determined in Table 1 below. The description of the variables in skewness and kurtosis are also presented in Table 1. The Jarque-Bera values are also presented with its probabilities to test the normality of the variables. The skewness is a measure of asymmetry of the distribution of the series around its mean. The skewness of a normal distribution is zero. With the exception of trade openess, the other variables normal distribution. The Jarque-Bera test is a statistic for testing whether or not the series are normally distributed. The null hypothesis of a normal distribution is rejected if the probability values are small. Therefore the null hypothesis of normality of variables is not rejected at 1 percent significant level for all the regression variables. 
Table 1: Descriptive Statistics of Regression Variables

\begin{tabular}{|l|c|c|c|c|c|}
\hline & $\mathrm{g}(\mathrm{GDPPC})$ & $\mathrm{EXV}$ & $\mathrm{g}(\mathrm{GCF})$ & $\mathrm{g}(\mathrm{SCER})$ & $\mathrm{TOP}$ \\
\hline Mean & 1.047126 & -2.351618 & 0.064621 & 0.023052 & 64.38442 \\
\hline Median & 0.424163 & -2.345798 & 0.053058 & 0.023350 & 64.51788 \\
\hline Maximum & 8.411696 & -2.345798 & 0.202355 & 0.034637 & 116.0484 \\
\hline Minimum & 0.000000 & -2.407359 & 0.000000 & 0.000000 & 11.54490 \\
\hline Std. Dev. & 1.850468 & 0.016549 & 0.041322 & 0.006194 & 27.55024 \\
\hline Skewness & 3.058364 & -2.831436 & 1.558476 & -1.798108 & 0.039150 \\
\hline Kurtosis & 11.66240 & 9.434707 & 5.827969 & 8.699864 & 2.238315 \\
\hline Jarque-Bera & 126.5080 & 85.71918 & 19.92690 & 51.09888 & 0.684010 \\
\hline Probability & 0.000000 & 0.000000 & 0.000047 & 0.000000 & 0.710345 \\
\hline Sum & 28.27239 & -65.84532 & 1.744777 & 0.622407 & 1802.764 \\
\hline Sum Sq. Dev. & 89.02999 & 0.007394 & 0.044396 & 0.000997 & 20493.42 \\
\hline Observations & 27 & 28 & 27 & 27 & 28 \\
\hline
\end{tabular}

Table 1 above presents information on the mean, the median, the maximum, the minimum, the standard deviation of variables, the skewness, the kurtosis, as well as the number of observations for of the explanatory variables the sample period 1983 to 2010. It can be observed that dispersion of variables over the sample period is quite high.

The descriptive results represented in Table 1 depicts an average economic growth of Ghana measured as growth in GDP per capita of Ghanaians from the period of 1983 to 2010 is 4.7 percent. The mean of the variables ranges from 0 per cent, as recorded by exchange rate volatility to 11.5 per cent.

Again, the standard deviation of the variables over this period were generally low except trade openess which recorded 27.6 per cent. Casual observation tends to show that for most of the cases, a higher mean is also associated with a higher standard deviation.

The skewness statistics is a measure of asymmetry of the distribution of the series around its mean. The skewness of a symmetric distribution, such as the normal distribution, is zero. The coefficients of skewness indicate that most of the series have positively skewed returns implying that most of the series have long lean right tails.

The kurtosis statistic indicates the peakness or flatness of the distribution of the series. The kurtosis of a normal distribution is 3 . The coefficients of kurtosis show that all the variables are positively skewed and leptokurtic relative to the normal distribution.

\section{Pair wise correlation matrix.}

Table 2 presents a pair wise correlation matrix. The pair wise correlation matrix shows that all the variables indicates a weaker relationship especially among the independent variables, hence the avoidance of any potential multicollinearity problems in the regression estimates. The correlation matrix shows a positive relationship between exchange rate volatility, growth rate in gross capita formation and growth rate in school enrollment but negatively correlated to trade.

Table 2: Pair wise Correlation Matrix Correlation Matrix

\begin{tabular}{|l|c|c|c|c|c|}
\hline & $\mathrm{g}(\mathrm{GDPPC})$ & $\mathrm{EXV}$ & $\mathrm{g}(\mathrm{GCF})$ & $\mathrm{g}(\mathrm{SCER})$ & $\mathrm{TOP}$ \\
\hline $\mathrm{g}(\mathrm{GDPPC})$ & 1.000000 & & & & \\
\hline $\mathrm{EXV}$ & 0.070944 & 1.000000 & & & \\
\hline $\mathrm{g}(\mathrm{GCF})$ & 0.008592 & -0.315835 & 1.000000 & & \\
\hline $\mathrm{g}($ SCER $)$ & 0.309244 & 0.031165 & 0.362211 & 1.000000 & \\
\hline TOP & -0.135448 & 0.251221 & -0.68524 & -0.135564 & 1.000000 \\
\hline
\end{tabular}

\section{Unit Root Test}

Though the ARDL model does not require pretesting of the variables for the order of integration, the variables involved need to be either $\mathrm{I}(0)$ or $\mathrm{I}(1)$ since the ARDL model would not be meaningful if there are $\mathrm{I}(2)$ variables. It is therefore necessary to test for unit root to be sure of the absence of I(2) variables. A formal test for stationary in regression variables is performed and presented in Table 5.4 below 
Table 3: Unit Root Test

\begin{tabular}{lcc}
\hline \hline \multicolumn{3}{c}{ Phillip Perron (PP) } \\
\hline g(GDPPC) & \multicolumn{1}{c}{$\mathbf{( 0 )}$} & I(1) \\
$\mathrm{g}(\mathrm{GCF})$ & $-5.912032^{* * * *}$ & \\
$\mathrm{EXV}$ & $-4.31757^{* * * *}$ & \\
$\mathrm{~g}(\mathrm{SCER})$ & $-5.469557^{* * * *}$ & \\
$\mathrm{TOP}$ & -0.167753 & $-6.89152^{* * *}$ \\
$* * *$ significant at 1 percent & -2.032152 & $-4.573766^{* * *}$ \\
\hline
\end{tabular}

The standard Phillip-Perron (PP) tests, is used to ascertain the order of integration for the variables. The tests indicate that all the variables apart from growth rate in school enrolment and trade openness are integrated to the order $\mathrm{I}(0)$. Growth in school enrollment rate and Trade openness is integrated to the I(1) order. Since there are no I(2) variables, the ARDL model is applicable to equation 10.1.

\section{Diagnostic Tests}

In order to ensure validity of the estimations so that they meet the classical linear regression model assumptions, standard diagnostic tests such as serial correlation, heteroscedasticity, normality of the disturbance term and functional form misspecification are considered. The diagnostic tests are presented in Table 5.5 below.

\section{Table 4: Diagnostic Tests}

\begin{tabular}{|c|c|c|}
\hline \multicolumn{3}{|c|}{ MODEL DIAGNOSTICS } \\
\hline Test Statistics & LM Version & F Version \\
\hline A:Serial Correlation & $* \mathrm{CHSQ}(1)=.012773[.910]^{*}$ & $\mathrm{~F}(1,18) \quad=.0088474[.926]^{*}$ \\
\hline B:Functional Form & $* \operatorname{CHSQ}(1)=18.6303[.000]^{*}$ & $\mathrm{~F}(1,18)=45.5030[.000]^{*}$ \\
\hline C:Normality & $* \operatorname{CHSQ}(2)=2.8248[.244] *$ & Not applicable \\
\hline D:Heteroscedasticity & ${ }^{*} \mathrm{CHSQ}(1)=20.3926[.000]^{*}$ & $\mathrm{~F}(1,24)=87.2807[.000]^{*}$ \\
\hline $\begin{array}{l}\text { ote: A: Lagrange mult } \\
: \text { Ramsey's RESET tes } \\
: \text { Based on a test of sk } \\
: \text { Based on the regress }\end{array}$ & $\begin{array}{l}\text { ier test of residual serial correl } \\
\text { sing the square of the fitted val } \\
\text { ness and kurtosis of residuals } \\
\text { n of squared residuals on squar }\end{array}$ & lues \\
\hline
\end{tabular}

Given the probability values of $0.926,0.000$ and 0.000 from table 5.5, the model passes all diagnostic tests. The null hypothesis tests are no serial correlation, correct functional form, normally distributed residuals and homoscedasticity in their order. The probability values show no evidence of auto correlation. The model passes the normality test, indicating a correct functional form specification and that the error is normally distributed. In other words the null hypotheses are not rejected.

\section{The Auto Regressive Distributed Lagged Approach \\ Bounds Test for Co-integration}

The Auto regressive Distributed lagged model requires the first step of bounds testing for the presence of a long-run relationship between the variables in equation (10) using an unrestricted error correction model as illustrated in equation 4.3. The maximum lag for the ARDL was set to one. The results of the bound test for cointegration analysis between the GDP per capita and its determinant are presented in Table 5.6. The values under the $\mathrm{I}(0)$ and $\mathrm{I}(1)$ are critical values for 5 regressors under 5 and 10 percent significant levels. The $\mathrm{I}(0)$ are the lower bound critical values whilst the I(1) are the upper bound critical values.

Table 5 Bounds Test

\begin{tabular}{|c|c|c|c|c|c|c|c|}
\hline \multicolumn{4}{|c|}{$F=9.4734$} & \multicolumn{4}{|c|}{$\mathrm{W}=47.3668$} \\
\hline \multicolumn{2}{|c|}{$5 \%$} & \multicolumn{2}{|c|}{$10 \%$} & \multicolumn{2}{|c|}{$5 \%$} & \multicolumn{2}{|c|}{$10 \%$} \\
\hline$\overline{I I(0)}$ & I(1) & $\mathrm{II}(0)$ & $\overline{\mathrm{I}(1)}$ & $\overline{I I(0)}$ & $\overline{\mathrm{I}(1)}$ & $\mathrm{I}(0)$ & $\overline{\mathrm{I}(1)}$ \\
\hline 2.6634 & 4.1407 & 2.1237 & 3.434 & 13.3168 & 20.7037 & 10.62 & 17.16 \\
\hline
\end{tabular}

Notes: Critical values are obtained from Microfit 5 
The ARDL F-statistic calculated, 9.4734, is above the 5 percent and 10 percent upper critical bounds computed by microfit 5. Since the computed F-statistic is above this upper bound critical value, the null hypothesis of no co integration is rejected. In other words there is a long run relationship among the variables of the model. Having established the existence of a long run relationship, the next step is to estimate the long run and short run coefficients of equation 4.4 and 4.5 respectively.

\section{Long- Run Estimates}

The long run estimates are derived from the estimation of a conditional ARDL specification of the growth model, equation 4.5. A maximum lag order of one is used in the estimation of the conditional ARDL model given the study sample size. The Microfit 5 software developed by PesaranHashem and PesaranBharam (1997) is used for the estimation of the models.. Table 6 below presents the results of the long run estimates.

Table 6: Long Run Estimates

\begin{tabular}{llll}
\hline & \multicolumn{2}{c}{ Dependent variable is g(GDPPC) } \\
\hline \hline EXV & Coefficient & Standard Error & T-Ratio[Prob] \\
$\mathrm{g}(\mathrm{GCF})$ & -1.7712 & .59259 & $-2.9889[.008]$ \\
$\mathrm{g}(\mathrm{SCER})$ & -49.4195 & 14.7823 & $-3.3431[.003]$ \\
$\mathrm{TOP}$ & 126.8548 & 44.8916 & $2.8258[.011]$ \\
\hline \hline
\end{tabular}

Note: ARDL (1,0,1,0,1) based on the Schwarz Bayesian Criterion

From table 6 , it is evident from the results that exchange rate volatility is negatively (-2.9889) related to economic growth (gGDPPC) in the long run and statistically significant at 1 percent. Thus a1 percent increase in exchange rate volatility would significantly decrease GDP per capita (economic growth) earnings by 2.9889 percent in the long run. This result is consistent with (Musyoki et al, 2012) who found a negative relationship between exchange rate volatility and economic growth in Kenya. Also (Ahmed 2009) investigated on the impact of exchange rate on economic growth using quarterly data from North America, Western and Eastern Europe. Their study points out that volatility of the exchange rate has negative and significant impact in the long run. However this results is in contrast with (Shehu \& Youtang 2012) who found a positive relationship between exchange rate volatility and economic growth in Ghana.

Furthermore the long run results indicate that gross capital formation has a negative impact on Ghana's economic growth (GDP per capita). It has a 1 percent significant coefficient of -3.3431 which implies that a 1 percent increase in the growth in physical capital stock would decrease Ghana's economic growth by 3.3431 percent.

The coefficient of trade openness was found to be negative and significant in the long run. The long run coefficient for trade openness is -3.5876 implying that a 1 percent increase in international trade would decrease Ghana's economic growth by 3.5876 percent in the long run. This result coincide with the conclusion of (Geza et al, 2011) who assert that instability of the exchange rate decreases the volume of international trade as it exposes importers and exporters to greater exchange rate risk due to fluctuations and therefore less willing to engage in international trade..

Finally, the long run results indicate the growth rate in human capital proxied by secondary school enrollment rate is also positively related to economic growth in Ghana. The coefficient of secondary school enrollment is 2.8258 and is also significant at 5 percent. This indicates that a 1 percent increase in human capital increase Ghana's gdp per capital (economic growth) by 2.8258 percent. This result implies that the more educated the people in Ghana, the more the economy grows.

\section{Short-Run Results}

The short run results associated with the long run estimates of the variables in the model is estimated by the error correction model (ECM) of the ARDL. The estimation results of the ECM based on Akaike Information Criterion are presented in Table 5.8. 
Table 7: Short run relationship between exchange rate volatility and economic growth

\begin{tabular}{|c|c|c|c|c|c|}
\hline & \multicolumn{2}{|l|}{ Coefficient } & Standard Error & \multicolumn{2}{|c|}{ T-Ratio[Prob] } \\
\hline DEXV & \multicolumn{2}{|l|}{-2.4940} & .94500 & \multicolumn{2}{|c|}{$-2.6391[.015]$} \\
\hline $\mathrm{D}(\mathrm{gGCF})$ & \multicolumn{2}{|l|}{-35.4840} & 16.8989 & \multicolumn{2}{|c|}{$-2.0998[.048]$} \\
\hline $\mathrm{D}$ (gSCER) & \multicolumn{2}{|l|}{178.6232} & 61.1044 & \multicolumn{2}{|c|}{$2.9232[.008]$} \\
\hline DTOP & \multicolumn{2}{|l|}{-.021202} & .030994 & \multicolumn{2}{|c|}{$-.68406[.501]$} \\
\hline $\operatorname{ECM}(-1)$ & \multicolumn{2}{|l|}{-.4081} & .19251 & \multicolumn{2}{|c|}{$-7.3143[.000]$} \\
\hline \multicolumn{2}{|l|}{ R-Squared } & .76928 & \multicolumn{2}{|c|}{ R-Bar-Squared } & .69642 \\
\hline \multicolumn{2}{|c|}{ S.E. of Regression } & 1.5926 & \multicolumn{2}{|c|}{ F-Stat. $F(4,21)$} & $15.8378[.000]$ \\
\hline \multicolumn{2}{|c|}{ Mean of dep. variable } & -.0027274 & \multicolumn{2}{|c|}{ S.D. of Dep. Variable } & 2.8905 \\
\hline \multicolumn{2}{|c|}{ Residual Sum of Squares } & 48.1900 & \multicolumn{2}{|c|}{ Equation Log-likelihood } & -44.9141 \\
\hline \multicolumn{2}{|c|}{ Akaike Info. Criterion } & -51.9141 & \multicolumn{2}{|c|}{ Schwarz Bayesian } & -56.3175 \\
\hline \multicolumn{2}{|c|}{ DW-statistic } & 1.9427 & & & \\
\hline
\end{tabular}

The Error Correction term, ECM(-1), in the model explain the speed of adjustment to restore equilibrium in the dynamic model. The ECM(-1)explains how quickly variables converge to equilibrium. According to Bannerjee et al (1998), a highly significant error correction term further confirms the existence of a stable long-run relationship. The coefficient of the lagged error correction term, -.4081 is negative and significant at 1 percent, confirming the existence of a long run relationship among the variables. It implies that the volatility of the exchange rate is corrected by 0.4081 percent in the model by the coming year. This means that more than 40.8 percent of the disequilibrium in the previous year is corrected in the current year. In other words if a shock (example is decrease in exchange rate) occurs, the speed of adjustment for correction is 40.8 percent. This speed of adjustment is relatively high in the model. All the short run estimated variables have the signs of their coefficients consistent with the long run estimates.

The immediate impact of exchange rate volatility is negative and significant at five percent. This result corroborates that of (Zahoor and Farooq 2009) who found a negative relationship between exchange rate volatility and economic growth in Pakistan. However, this result is inconsistent with (Azeez et. al 2012) who found a positive relationship between exchange rate volatility and macroeconomic performance in Nigeria. The empirical result indicates that exchange rate volatility is significant and has a negative relationship on economic growth in the Ghanaian economy in the short run.

Growth in the gross capital formation maintains its negative sign and significant at 5 percent in the short-run. Thus a 1percent increase in physical capital stock would cause a significant effect on Ghana's economy by 2.0998 percent. Secondary school enrollment rate is significant at one percent and positively related to economic growth in the short run . This indicates that a 1 percent increase in school enrollment rate would cause a significant 0.68406 percent decrease in economic growth.

Therefore, exchange rate volatility plays a significant role in determining exports, imports and overall economic growth. Arize (1998) has found that there is a negative effect of exchange rate volatility on imports as well as exports and this effect is significant in the long and short run. This is because of risk transfer from highly volatile investment to less risky ones by risk averse investors led many researchers to suggest that there exists a negative effect of exchange rate volatility on volume of trade because of increase in this risk level (De Grauwe, 1988). Barkoulas et al (2002) examined the impact of exchange rate fluctuation on the volume and variability of trade flows. They concluded that, exchange rate volatility discourages expansion of the volume of trade thereby reducing its benefits. Eichengreen and Leblang (2003) carried out their research in 12 countries over a period of 120 years and found strong inverse relationship between exchange rate stability and growth.

\section{Exchange rate volatility based on ARCH/ GARCH models.}

This study will employ GARCH $(1,1)$ as the GARCH process to capture the exchange ratevolatility. This is because using the Akaike information criterion and the Schwarz criterion, the results of GARCH $(1,1)$ as shown in Table 5.1 below turned out to be the most robust. 
Table 8: GARCH (1,1) Estimation Results

(Dependent Variable: LNRER)

\begin{tabular}{crcrr}
\hline \hline \multicolumn{1}{c}{ Variable } & Coefficient & Std. Error & z-Statistic & Prob. \\
\hline \hline C & 0.000303 & 0.015640 & 0.019390 & 0.9845 \\
RER(-1) & 1.004937 & 0.016386 & 61.32722 & 0.0000 \\
\hline \hline \multicolumn{5}{c}{ Variance Equation } \\
RESID(-1)^2 & 0.000538 & 0.000533 & 1.009081 & 0.3129 \\
GARCH(-1) & 0.005330 & $7.65 \mathrm{E}-05$ & -69.68371 & 0.0000 \\
\hline \hline R-squared & 0.587200 & 0.410638 & 1.429971 & 0.1527 \\
Adjusted R-squared & 0.995534 & Mean dependent var & 0.488392 \\
S.E. of regression & 0.995520 & S.D. dependent var & 0.432274 \\
Sum squared resid & 0.028932 & Akaike info criterion & -4.168811 \\
Log likelihood & 0.278747 & Schwarz criterion & -4.111884 \\
Durbin-Watson stat & 703.2758 & Hannan-Quinn criter. & -4.146116 \\
\hline \hline
\end{tabular}

\section{Estimation of volatility index.}

Table 5.1 above displays the results of the monthly real exchange rate volatility measure for Ghana from January 1983 to December 2010 using GARCH approach. The results shown in Table 5.1 suggest that the exchange rate follows a GARCH $(1,1)$ procedure, as that turned out to be the most robust. From the results the mean and variance equations are specified in equations (i)and (ii), respectively:

$$
\begin{aligned}
& R E R=0.000303+1.004937 R E R(-1) \\
& \sigma_{t}^{2}=0.000538-0.005330 \varepsilon_{t-1}^{2}+0.587200 \sigma_{t-1}^{2}
\end{aligned}
$$

The result obtained from the conditional variance equation indicates that mean $\varphi$ from equation (ii) is positive, hence indicating a proper specification of the conditional variance, which is statistically significant at the 1 per cent level. Also, the result shows that previous information about volatility, measured as the lag of the squared residual from the mean equation (ARCH term) is negative and the previous forecast error variance (the GARCH term) is positive. The sum of the coefficients of these two variables (ARCH and GARCH term) is positive close to unity meaning that the volatility shocks are persistent. Figure 8 below shows the trend in the volatility of the exchange rate from 1983 to 2010.

\section{Conclusion}

The objective of this study was to examine empirically the impact of real exchange rate volatility on economic growth into a developing country like Ghana. This was motivated by the fact that worldwide exchange rate issues are regarded as important determinants of economic growth; I deemed it important to undertake this study because no research has been done in exchange rate volatility with respect to economic growth in Ghana. This study estimated real exchange rate volatility in Ghana from 1983 to 2010 (monthly data). The study revealed that the impact of real exchange rate volatility on economic growth is significantly negative; thereby confirming other studies that real exchange rate volatility discourages investors due to the high level of risk involved in trade thereby reducing trade and productivity in the economy.(De Grauwe, 1998; Barkoulas et al 2002; Eichengreen and Leblang ,2003). The growth in physical capital stock proxied by gross capital formation and trade openness revealed negative relationship and was found to play active role in determining economic growth. The study also found that trade openness (international trade) in Ghana play a significantly positive role in determining economic growth. The Auto regressive Distributed Lag Bounds testing approach to cointegration reveals a long run relationship between Ghana's economic growth, exchange rate volatility, trade openness, physical capital stock and human capital stock. Both long run and short run estimates show that exchange rate volatility, trade openness and physical capital stock have significant negative effects on economic growth. The study also shows that human capital stock proxied by growth in school enrollment rate is positively related to economic growth both the long and short run. The empirical findings are in conformity with (Ibikunle and Isaac 2011) results and in contrast to (Aliye 2010) finding. Conclusively, the findings support various economic researchers which suggest the exchange rate can be effective to for economic development (Matto \& Subramanian 2009). 


\section{References}

Abeysinghe, T., \&Yeok, T. L. (1998). Exchange rate appreciation and export competitiveness. The case of Singapore. Applied economics, 30(1), 51-55.

Ahmed, M. S. (2009). An Empirical Study on Exchange Rate Volatility and it Impacts on Bilateral Export Growth: Evidence from Bangladesh.

Aizenman, J. (1992). Exchange rate flexibility, volatility, and domestic and foreign direct investment. Staff Papers, 39(4), 890-922.

Akhtar, M. A., \& Hilton, R. S. (1984). Exchange rate uncertainty and international trade: Some conceptual issues and new estimates for Germany and the United States. Federal Reserve Bank.

Alagidede, P., \& Ibrahim, M. (2017). On the causes and effects of exchange rate volatility on economic growth: Evidence from Ghana. Journal of African Business, 18(2), 169-193.

Aliyu, S. U. R. (2009). Impact of oil price shock and exchange rate volatility on economic growth in Nigeria: An empirical investigation.

Amoah, L., \&Aziakpono, M. J. (2017). Exchange Rate Behavior in Ghana: Is there a Misalignment?. The Journal of Developing Areas, 51(4), 261-276.

Arize, A. C. (1995). The effects of exchange-rate volatility on US exports: an empirical investigation. Southern Economic Journal, 34-43.

Asesnso- Okyere, W.K, \&Yahaya, K, (1993). International Trade and Payment Development Policies and Options.in Policies and Options for Ghanaian Economic Development Edited by Nyanteng, V.K., ISSER.

Asseery, A., \& Peel, D. A. (1991). The effects of exchange rate volatility on exports: Some new estimates. Economics letters, 37(2), 173-177.

Bacchetta, P., \& Van Wincoop, E. (2000). Does exchange-rate stability increase trade and welfare?. American Economic Review, 90(5), 1093-1109.

Bahmani- Oskooee, M., \&Kovyryalova, M. (2008). Impact of exchange rate uncertainty on trade flows: Evidence from commodity trade between the United States and the United Kingdom. World Economy, 31(8), 1097-1128.

Barkoulas, J. T., Baum, C. F., \&Caglayan, M. (2002).Exchange rate effects on the volume and variability of trade flows. Journal of International Money and Finance, 21(4), 481-496.

Bhasin, V. K. (2004). Dynamic inter-links among the exchange rate, price level and terms of trade in a managed floating exchange rate system: The case of Ghana.

Bollerslev, T. (1986).Generalized autoregressive conditional heteroskedasticity. Journal of econometrics, 31(3), 307327.

Brada, J. C., \& Mendez, J. (1988).Exchange rate risk, exchange rate regime and the volume of international trade.Kyklos, 41(2), 263-280.

David, O., Umeh, J. C., \&Ameh, A. A. (2010).The effect of exchange rate fluctuations on the Nigerian manufacturing sector. African journal of business management, 4(14), 2994-2998.

De Grauwe, P. (1988). Exchange rate variability and the slowdown in growth of international trade. Staff Papers, 35(1), 63-84.

De Vita, G., \& Abbott, A. (2004). The impact of exchange rate volatility on UK exports to EU countries. Scottish Journal of Political Economy, 51(1), 62-81.

Doğanlar, M. (2002).Estimating the impact of exchange rate volatility on exports: evidence from Asian countries. Applied Economics Letters, 9(13), 859-863.

Dordunoo, C. K. (1994). The foreign exchange market and the Dutch auction system in Ghana.

Eichengreen, B., \&Leblang, D. (2003). Capital account liberalization and growth: was Mr. Mahathir right?. International Journal of Finance \& Economics, 8(3), 205-224.

Engle, R. F. (1982). Autoregressive conditional heteroscedasticity with estimates of the variance of United Kingdom inflation. Econometrica: Journal of the Econometric Society, 987-1007.

Esquivel, G., \&Larraín, F. (2002). The impact of $G$-3 exchange rate volatility on developing countries.UN.

Frankel, J., \& Rose, A. (2002).An estimate of the effect of common currencies on trade and income. The Quarterly Journal of Economics, 117(2), 437-466.

Goldberg, L. S. (1993). Exchange rates and investment in United States industry. The Review of Economics and Statistics, 575-588.

Gotur, P. (1985). Effects of exchange rate volatility on trade: some further evidence. Staff Papers, 32(3), 475-512.

Grier, K. B., \&Tullock, G. (1989).An empirical analysis of cross-national economic growth, 1951-1980. Journal of monetary economics, 24(2), 259-276.

Growth: A Comparative Analysis for Russia Japan and China. Research Journal of International Studies, 8, 98 -111 
Hooper, P., \&Kohlhagen, S. W. (1978). The effect of exchange rate uncertainty on the prices and volume of international trade. Journal of international Economics, 8(4), 483-511.

Hooper, P., \&Kohlhagen, S. W. (1978). The effect of exchange rate uncertainty on the prices and volume of international trade. Journal of international Economics, 8(4), 483-511.

Jin, G (2008). The Impact of Oil Price Shock and Exchange Rate Volatility on Economic

Kenen, P. B., \&Rodrik, D. (1986). Measuring and analyzing the effects of short-term volatility in real exchange rates. The Review of Economics and Statistics, 311-315.

Kenen, P. B., \&Rodrik, D. (1986). Measuring and analyzing the effects of short-term volatility in real exchange rates. The Review of Economics and Statistics, 311-315.

Koray, F., \&Lastrapes, W. D. (1989). Real exchange rate volatility and US bilateral trade: a VAR approach. The Review of Economics and Statistics, 708-712.

Kormendi, R. C., \&Meguire, P. G. (1985). Macroeconomic determinants of growth: cross-country evidence. Journal of Monetary economics, 16(2), 141-163.

Mensah, L., Bokpin, G. A., \& Dei Fosu-Hene, E. (2017).Foreign exchange rate moments and FDI in Ghana. Journal of Economics and Finance, 41(1), 136-152.

Obstfeld, M., \&Rogoff, K. (1998). Risk and exchange rates(No. w6694). National bureau of economic research.

Persson, T., \&Svensson, L. E. (1989). Why a stubborn conservative would run a deficit: Policy with time-inconsistent preferences. The Quarterly Journal of Economics, 104(2), 325-345.

Pesaran, M. H., Shin, Y., \& Smith, R. J. (2001).Bounds testing approaches to the analysis of level relationships.Journal of applied econometrics, 16(3), 289-326.

Razazadehkarsalari, A., Haghir, F., \&Behrooznia, A. (2011).The effect of exchange rate fluctuations on real GDP in Iran.American Journal of Scientific Research Issue, 26, 6-18.

Schnabl, G. (2008). Exchange rate volatility and growth in small open economies at the EMU periphery. Economic Systems, 32(1), 70-91.

Thursby, J. G., \&Thursby, M. C. (1987). Bilateral trade flows, the Linder hypothesis, and exchange risk.

Zhang, Z. (1999). China's exchange rate reform and its impact on the balance of trade and domestic inflation. The Asia Pacific Journal of Economics \& Business, 3(2), 4. 